\title{
Association between serum soluble Toll-like receptor 2 and 4 and the risk of breast cancer
}

\author{
GHADA EL-KHARASHY ${ }^{1}$, AHMED GOWILY ${ }^{2}$, TAREK OKDA $^{1}$ and MAHA HOUSSEN ${ }^{1}$ \\ ${ }^{1}$ Department of Biochemistry, Faculty of Pharmacy, Damanhour University, Damanhour 22511; \\ ${ }^{2}$ Department of Oncology Medicine, Faculty of Medicine, Alexandria University, Alexandria 21111, Egypt
}

Received April 7, 2020; Accepted October 14, 2020

DOI: $10.3892 / \mathrm{mco} .2020 .2200$

\begin{abstract}
Soluble Toll-like receptor (sTLR) 2 and 4 are endogenous negative regulators of TLR2 and TLR4 signaling. Therefore, the present study aimed to determine the serum levels of sTLR 2 and 4, and to investigate the association between their levels and the clinicopathological parameters of patients with breast cancer. A total of 100 female patients with breast cancer (50 non-metastatic and 50 metastatic), as well as 50 healthy control volunteers were enrolled in the present study, and serum levels of sTLR2 and 4 were determined by ELISA. A significant increase in serum sTLR 2 was detected in patients with non-metastatic $(2,258.2 \pm 1,832.44 \mathrm{pg} / \mathrm{ml})$ and metastatic $(5,997.4 \pm 8,585.23 \mathrm{pg} / \mathrm{ml})$ breast cancer, compared with the control group $(1,106.8 \pm 99.93 \mathrm{pg} / \mathrm{ml} ; \mathrm{P}=0.0001)$. A significant increase in serum sTLR4 was also detected in patients with both non-metastatic $(1,945.2 \pm 1,709.53 \mathrm{pg} / \mathrm{ml})$ and metastatic breast cancer $(7,800.1 \pm 13,041.28 \mathrm{pg} / \mathrm{ml})$, compared with the control group $(1,106.8 \pm 108.32 \mathrm{pg} / \mathrm{ml} ; \mathrm{P}=0.0001)$. Furthermore, a positive correlation was observed between the levels of serum sTLR4 and 2 and clinicopathological parameters, such as progesterone receptor and estrogen receptor expression. In conclusion, sTLR 2 and sTLR4 may be potential biomarkers of breast cancer susceptibility.
\end{abstract}

\section{Introduction}

Breast cancer is the leading global cause of cancer-related death in females, and represents a major worldwide health issue (1). In Egypt, breast cancer is a major threat to the female population, representing $18.9 \%$ of total cancer cases (2).

Toll-like receptors (TLRs) are usually expressed by immune cells such as macrophages, dendritic cells, mast cells and eosinophils, as well as some epithelial cells (3). TLRs play

Correspondence to: Professor Maha Houssen, Department of Biochemistry, Faculty of Pharmacy, Damanhour University, El Gomhoria Street, Damanhour 22511, Egypt

E-mail: mahahoussen@yahoo.com

Key words: breast cancer, non-metastatic, metastatic, soluble Toll-like receptor 2, soluble Toll-like receptor 4 a central role in the recognition of harmful molecules from invading microorganisms or internal tissue damage, activating specific transcriptional responses including the $\mathrm{NF}-\kappa \mathrm{B}$, Mitogen-activated protein kinase and interferon regulatory factor pathways, which result in inflammation (4). TLR4 was the first TLR to be discovered in humans, and is one of the most conspicuous members of the TLR family, expressed by both immune and non-immune cells (5). Upregulation of TLR4 is positively associated with the increased occurrence of metastasis in patients with breast cancer (6).

TLR2 is expressed by numerous cell types of the innate and adaptive immune systems (7). Stimulation of TLR2 on the surface of breast cancer cells has been reported to increase disease severity by promoting NF- $\kappa \mathrm{B}$ signaling (8). Furthermore, increasing evidence suggests that TLR2 signaling may protect tumor cells from host immune surveillance and attack (8).

Dynamic regulation of TLR signaling is essential to the prevention of chronic inflammation and tissue destruction (9). A number of mechanisms have been reported to negatively regulate TLR responses, including cell membrane-bound TLR suppressors and soluble TLRs (sTLRs) (9). One of the major negative regulators of TLR-signaling is the generation of extracellular sTLRs, which serve as decoy receptors to impede ligand-induced signaling (10). In the human immune system, sTLR2 is reported to suppress TLR2-mediated inflammation in part by preventing binding to its co-receptor CD14 (11). sTLR2 is believed to be generated by protease cleavage or ectodomain shedding, resulting in $\geq 6$ distinct sTLR2 polypeptides, which have been identified in human breast milk, plasma and monocyte culture supernatants (12). A soluble form of the extracellular TLR4 domain (sTLR4) and myeloid differentiation factor 2 (MD-2) combine to form an sTLR4/MD-2 complex which inhibits TLR4 signaling, potentially by preventing the interaction between membrane-bound TLR4 and its ligand (13).

In summary, numerous research groups have reported that TLRs are expressed on both host immune and tumor cells, where they influence the immune response, uncontrolled tumor proliferation, resistance to apoptosis, metastasis and tumor cell escape from immune surveillance (14).

A number of concerns about the impact of the endogenous negative regulation of TLR signaling on host immune and tumor cells remain unresolved. On this basis, the aim of the 
Table I. Clinical characteristics of the studied group.

\begin{tabular}{|c|c|c|c|c|c|c|c|c|}
\hline Characteristics & $\begin{array}{l}\text { Group I } \\
\text { control }\end{array}$ & $\begin{array}{c}\text { Group II } \\
\text { 'non metastatic' }\end{array}$ & $\begin{array}{l}\text { Group III } \\
\text { 'metastatic' }\end{array}$ & $\chi^{2}$ test & P-value & $\mathrm{P} 1$ & $\mathrm{P} 2$ & P3 \\
\hline Age, years & & & & 12.25 & $0.013^{\mathrm{a}}$ & $0.013^{\mathrm{a}}$ & $0.002^{\mathrm{a}}$ & 0.282 \\
\hline Range & $28-66$ & $30-69$ & $32-71$ & & & & & \\
\hline Mean \pm SD & $46.0 \pm 11.05$ & $50.9 \pm 10.62$ & $52.0 \pm 8.67$ & & & & & \\
\hline Family history, n (\%) & & & & 5.21 & $0.026^{\mathrm{a}}$ & $0.025^{\mathrm{a}}$ & 0.311 & 0.070 \\
\hline Negative & $39(78.0)$ & $46(92.0)$ & $41(82.0)$ & & & & & \\
\hline Positive & $11(22.0)$ & $4(8.0)$ & $9(18.0)$ & & & & & \\
\hline Lactation history, n (\%) & & & & 2.32 & 0.125 & 0.365 & 0.111 & 0.189 \\
\hline No & $8(16.0)$ & $5(10.0)$ & $4(8.0)$ & & & & & \\
\hline Yes & $42(84.0)$ & $45(90.0)$ & $46(92.0)$ & & & & & \\
\hline No of children, n (\%) & & & & 1.65 & 0.366 & 0.296 & 0.216 & 0.409 \\
\hline $1-3$ & $22(44.0)$ & $19(38.0)$ & $22(44.0)$ & & & & & \\
\hline $4-5$ & $18(36.0)$ & $22(44.0)$ & $22(44.0)$ & & & & & \\
\hline $6+$ & $4(8.0)$ & $4(8.0)$ & $6(12.0)$ & & & & & \\
\hline
\end{tabular}

${ }^{\mathrm{a}} \mathrm{P}<0.05$. P1, comparison between the control and non-metastatic groups; $\mathrm{P} 2$, comparison between the control and metastatic groups; $\mathrm{P} 3$, comparison between the metastatic and non-metastatic groups.

present study was to assess the serum levels of sTLR2 and 4 as negative regulators of TLR2 and TLR4 signaling, and to investigate their association with the clinicopathological parameters of patients with breast cancer.

\section{Subjects and methods}

Subjects. A total of 150 female subjects were recruited into the present study, and were classified into the following groups: Group I, 50 healthy control subjects with no history of breast cancer; Group II, 50 subjects recently diagnosed with non-metastatic breast cancer; and Group III, 50 subjects with metastatic breast cancer. All patients were recruited from the Damanhour Oncology Center (Damanhour, Egypt) between August 2016 and December 2018. Demographics data were obtained from all participants and included age, menopausal status, number of children, lactation history, marital status and family history of breast cancer. The present study was approved by the ethics committee of Damanhour oncology center (reference no. 3/8 PB4) and informed consent was obtained from each participant.

Exclusion criteria. Patients with autoimmune diseases, other types of malignancy, liver and kidney diseases were excluded from the present study.

Sample collection. A 5-ml sample of whole blood was collected from each subject after an overnight fast. The blood samples were allowed to clot for $15 \mathrm{~min}$ at room temperature and then centrifuged for $10 \mathrm{~min}$ at $12,000 \mathrm{x} \mathrm{g}(14.810 \mathrm{~g})$. The separated serum was stored at $-20^{\circ} \mathrm{C}$ for the assessment of serum sTLR2 and sTLR4 levels by ELISA.

Measurement of serum sTLRs. The levels of serum sTLR 2 and 4 were determined using Human Soluble Toll-like receptor 2 and 4 ELISA kits (cat. nos. In-Hu4102 and In-Hu4103, respectively; Bioneovan Co., Ltd.), according to the manufacturer's protocols.

Statistical analysis. The data were analyzed using the SPSS software package version 20.0 (IBM Corp). Qualitative data are presented as counts and percentages. Comparisons between the categorical variables of different groups were assessed using the $\chi^{2}$ test. Normally distributed quantitative data are presented as the mean \pm standard deviation, while non-normally distributed data are expressed as the median, minimum and maximum values. For normally distributed data, comparisons between $\geq 2$ groups were conducted using the F-test (one-way ANOVA) Duncan method. For correlation analysis, the Pearson's correlation coefficient (r) was calculated.

Receiver operating characteristic (ROC) curve statistics were applied to determine assay sensitivity and specificity. In order to determine the diagnostic accuracy of the combination of biomarkers, logistic regression analysis was used to estimate the predicted probabilities, which were subsequently used to generate a ROC curve. The method described by DeLong was used for comparing the area under the ROC curves (AUCs). $\mathrm{P} \leq 0.05$ was considered to indicate a statistically significant difference, and significance test results are quoted as two-tailed probabilities.

\section{Results}

Demographical data. Patients in both the metastatic and non-metastatic breast cancer groups were significantly older than those in the control group $(\mathrm{P}=0.013$ and $\mathrm{P}=0.002$, respectively; Table I). A family history of breast cancer was also significantly more likely in patients with non-metastatic breast cancer than in healthy controls $(\mathrm{P}=0.025$; Table I). No significant differences were detected between patients with 
Table II. Clinical characteristics of patients with breast cancer.

\begin{tabular}{|c|c|c|c|c|c|c|}
\hline \multirow[b]{2}{*}{ Patient characteristics } & \multicolumn{2}{|c|}{$\begin{array}{c}\text { Group II } \\
\text { 'non metastatic' }\end{array}$} & \multicolumn{2}{|c|}{$\begin{array}{l}\text { Group III } \\
\text { 'metastatic' }\end{array}$} & \multirow[b]{2}{*}{$\chi^{2}$ test } & \multirow[b]{2}{*}{ P-value } \\
\hline & No. & $\%$ & No. & $\%$ & & \\
\hline Menopausal status & & & & & 2.36 & 0.2140 \\
\hline Premenopausal & 21 & 42.0 & 24 & 48.0 & & \\
\hline Postmenopausal & 29 & 58.0 & 26 & 52.0 & & \\
\hline Pathology & & & & & 2.08 & 0.1060 \\
\hline Infiltrating ductal carcinoma & 44 & 88.0 & 48 & 96.0 & & \\
\hline Infiltratin globular carcinoma & 6 & 12.0 & 2 & 4.0 & & \\
\hline HER 2 & & & & & 4.083 & $0.0433^{\mathrm{a}}$ \\
\hline Positive & 30 & 60.0 & 37 & 74.0 & & \\
\hline Negative & 20 & 40.0 & 13 & 26.0 & & \\
\hline PR & & & & & 4.504 & $0.0330^{\mathrm{a}}$ \\
\hline Positive & 16 & 32.0 & 9 & 18.0 & & \\
\hline Negative & 34 & 68.0 & 41 & 82.0 & & \\
\hline ER & & & & & 0.000 & $>0.9999$ \\
\hline Positive & 10 & 20.0 & 10 & 20.0 & & \\
\hline Negative & 40 & 80.0 & 40 & 80.0 & & \\
\hline Lymphovascular invasion & & & & & 13.2 & $0.0010^{\mathrm{a}}$ \\
\hline Positive & 12 & 24.0 & 23 & 46.0 & & \\
\hline Negative & 38 & 76.0 & 27 & 54.0 & & \\
\hline T stage & & & & & 173.1 & $0.0010^{\mathrm{a}}$ \\
\hline I & 2 & 4.0 & 20 & 40.0 & & \\
\hline II & 27 & 54.0 & 24 & 48.0 & & \\
\hline III & 19 & 38.0 & 5 & 10.0 & & \\
\hline IV & 2 & 4.0 & 1 & 2.0 & & \\
\hline $\mathrm{N}$ stage & & & & & 297.5 & $0.0010^{\mathrm{a}}$ \\
\hline 0 & 1 & 2.0 & 18 & 36.0 & & \\
\hline 1 & 11 & 22.0 & 9 & 18.0 & & \\
\hline 2 & 24 & 48.0 & 19 & 38.0 & & \\
\hline 3 & 14 & 28.0 & 4 & 8.0 & & \\
\hline M stage & & & & & 25.6 & $0.0001^{\mathrm{a}}$ \\
\hline Positive & 0 & 0.0 & 50 & 100.0 & & \\
\hline Negative & 50.0 & 100.0 & 0 & 0.0 & & \\
\hline Grade & & & & & 36.2 & $0.0001^{\mathrm{a}}$ \\
\hline I & 38 & 76.0 & 3 & 6.0 & & \\
\hline II & 11 & 22.0 & 44 & 88.0 & & \\
\hline III & 1 & 2.0 & 3 & 6.0 & & \\
\hline Presentation & & & & & 504.417 & $0.001^{\mathrm{a}}$ \\
\hline Breast lump & 38 & 76.0 & 0 & 0.0 & & \\
\hline Nipple retraction & 4 & 8.0 & 47 & 94.0 & & \\
\hline Inflammed swollen breast & 1 & 2.0 & 1 & 2.0 & & \\
\hline Nipple and areola ulcer & 1 & 2.0 & 1 & 2.0 & & \\
\hline Nipple discharge & 6 & 12.0 & 1 & 2.0 & & \\
\hline
\end{tabular}

${ }^{a} \mathrm{P}<0.05$. P1, comparison between the control and non-metastatic groups; P2, comparison between the control and metastatic groups; P3, comparison between the metastatic and non-metastatic groups. T, tumor size; ER, estrogen receptor; N, lymph node status; PR, progesterone receptor; M, metastatic status; HER2, human epidermal growth factor receptor 2.

breast cancer and the controls with respect to lactation history and number of children (Table I).
A significant increase in the number of grade III patients was detected among those with metastatic, compared with 
Table III. sTLR2 in the studied groups.

\begin{tabular}{|c|c|c|c|c|c|c|c|c|}
\hline sTLR2 & $\begin{array}{l}\text { Group I } \\
\text { control }\end{array}$ & $\begin{array}{c}\text { Group II } \\
\text { 'non metastatic' }\end{array}$ & $\begin{array}{l}\text { Group III } \\
\text { 'metastatic' }\end{array}$ & $\begin{array}{l}\text { ANOVA } \\
\text { test }\end{array}$ & P-value & $\mathrm{P} 1$ & $\mathrm{P} 2$ & P3 \\
\hline Range, pg/ml & $823-1349$ & $1,043.5-8,460$ & $1,143.5-23,895$ & & & & & \\
\hline Mean \pm SD, pg/ml & $1,106.8 \pm 99.93$ & $2,258.2 \pm 1,832.44$ & $5,997.4 \pm 8,585.23$ & 33.2 & $0.0001^{\mathrm{a}}$ & $0.0001^{\mathrm{a}}$ & $0.0001^{\mathrm{a}}$ & $0.0001^{\mathrm{a}}$ \\
\hline
\end{tabular}

Table IV. Serum sTLR4 in the studied groups.

\begin{tabular}{|c|c|c|c|c|c|c|c|c|}
\hline sTLR4 & $\begin{array}{l}\text { Group I } \\
\text { control }\end{array}$ & $\begin{array}{c}\text { Group II } \\
\text { 'non metastatic' }\end{array}$ & $\begin{array}{l}\text { Group III } \\
\text { 'metastatic' }\end{array}$ & $\begin{array}{l}\text { ANOVA } \\
\text { test }\end{array}$ & P-value & $\mathrm{P} 1$ & $\mathrm{P} 2$ & P3 \\
\hline Range, pg/ml & $923-1,296$ & $1,210.5-7,285$ & $1,002-33,615$ & & & & & \\
\hline Mean $\pm \mathrm{SD}, \mathrm{pg} / \mathrm{ml}$ & $1,106.8 \pm 108.32$ & $1,945.2 \pm 1,709.53$ & $7,800.1 \pm 13,041.28$ & 32.1 & $0.0001^{\mathrm{a}}$ & $0.0001^{\mathrm{a}}$ & $0.0001^{\mathrm{a}}$ & $0.0001^{\mathrm{a}}$ \\
\hline
\end{tabular}

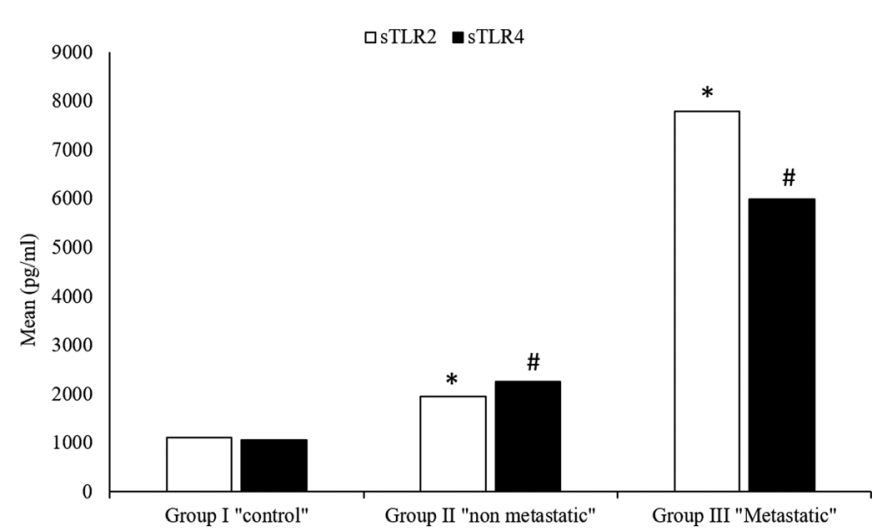

Figure 1. Serum sTLR2 and sTLR4 in the study and control groups. ${ }^{*} \mathrm{P}<0.05$ vs. control for sTLR2; ${ }^{\text {P }}<0.05$ vs. control for sTLR4. sTLR, soluble Tolllike receptor.

those with non-metastatic breast cancer ( $\mathrm{P}=0.0001$; Table II). Patients with non-metastatic breast cancer showed a significant increase in tumor size and regional lymph node involvement compared with the metastatic patients $(\mathrm{P}=0.001)$. Moreover, a significant increase in distant metastasis was also observed in the metastatic, compared with the non-metastatic patients $(\mathrm{P}=0.0001$; Table II).

The patients with metastatic breast cancer also exhibited a significant increase in human epidermal growth factor 2 receptor (HER2) expression compared with the non-metastatic patients $(\mathrm{P}=0.0433)$. However, a significant increase in progesterone receptor (PR) expression was detected in the non-metastatic, compared with the metastatic patients $(\mathrm{P}=0.033$; Table II). A significant increase in the number of breast lumps was detected in non-metastatic breast cancer compared with metastatic patients. On the other hand, a significant increase in nipple retraction was observed in
Table V. Pearson's correlation between both serum sTLR2 and serum sTLR4 and clinical characteristics of patients with breast cancer.

\begin{tabular}{|c|c|c|}
\hline Parameters & sTLR4 & sTLR2 \\
\hline \multicolumn{3}{|l|}{ HER2 } \\
\hline$R$ value & -0.004 & -0.018 \\
\hline P-value & 0.971 & 0.859 \\
\hline \multicolumn{3}{|l|}{ PR } \\
\hline $\mathrm{R}$ value & 0.196 & 0.142 \\
\hline P-value & $0.051^{\mathrm{a}}$ & 0.160 \\
\hline \multicolumn{3}{|l|}{ ER } \\
\hline $\mathrm{R}$ value & 0.098 & 0.099 \\
\hline P-value & 0.332 & 0.327 \\
\hline \multicolumn{3}{|c|}{ Lymphovascular invasion } \\
\hline $\mathrm{R}$ value & 0.192 & -0.011 \\
\hline P-value & 0.056 & 0.914 \\
\hline \multicolumn{3}{|l|}{ M stage } \\
\hline $\mathrm{R}$ value & -0.303 & -0.291 \\
\hline P-value & $0.002^{\mathrm{a}}$ & $0.003^{\mathrm{a}}$ \\
\hline \multicolumn{3}{|l|}{$\mathrm{N}$ stage } \\
\hline $\mathrm{R}$ value & 0.093 & -0.070 \\
\hline P-value & 0.355 & 0.487 \\
\hline \multicolumn{3}{|l|}{ T stage } \\
\hline$R$ value & -0.023 & -0.101 \\
\hline P-value & 0.819 & 0.316 \\
\hline \multicolumn{3}{|l|}{ Grade } \\
\hline $\mathrm{R}$ value & 0.009 & -0.101 \\
\hline P-value & 0.928 & 0.319 \\
\hline
\end{tabular}

${ }^{\text {a }} \mathrm{P}<0.05$. sTLR, soluble Toll-like receptor; HER2, epidermal growth factor receptor $2 ; \mathrm{T}$, tumor size; $\mathrm{PR}$, progesterone receptor; $\mathrm{N}$, regional lymph node; ER, estrogen receptor; $\mathrm{M}$, distant metastasis. 
Table VI. Sensitivity, specificity and accuracy of sTlr2, sTLR4 and sTLR4/sTLR2 detection.

\begin{tabular}{|c|c|c|c|c|c|c|c|c|c|c|}
\hline \multirow[b]{2}{*}{ sTLR } & \multirow[b]{2}{*}{ AUC } & \multirow[b]{2}{*}{$\begin{array}{l}\text { Std. } \\
\text { Error }\end{array}$} & \multirow[b]{2}{*}{ P-value } & \multicolumn{2}{|c|}{$\begin{array}{c}\text { Asymptotic } \\
95 \% \text { confidence } \\
\text { interval }\end{array}$} & \multirow[b]{2}{*}{$\begin{array}{c}\text { Sensitivity, } \\
\%\end{array}$} & \multirow[b]{2}{*}{$\begin{array}{c}\text { Specificity, } \\
\%\end{array}$} & \multirow[b]{2}{*}{$\begin{array}{c}\text { Accuracy } \\
\%\end{array}$} & \multirow[b]{2}{*}{$\begin{array}{c}\mathrm{PPV}, \\
\%\end{array}$} & \multirow[b]{2}{*}{$\begin{array}{c}\text { NPV, } \\
\%\end{array}$} \\
\hline & & & & $\begin{array}{l}\text { Lower } \\
\text { bound }\end{array}$ & $\begin{array}{l}\text { Upper } \\
\text { bound }\end{array}$ & & & & & \\
\hline sTlr2 & 0.634 & 0.052 & 0.008 & 0.532 & 0.735 & 65.0 & 70.0 & 69.0 & 72.0 & 64.0 \\
\hline sTLR4 & 0.582 & 0.047 & 0.323 & 0.390 & 0.574 & 59.0 & 64.0 & 62.0 & 55.0 & 67.0 \\
\hline sTLR4-sTLR2 & 0.611 & 0.059 & 0.217 & 0.457 & 0.686 & 63.0 & 64.0 & 62.0 & 58.0 & 69.0 \\
\hline
\end{tabular}

sTLR, soluble Toll-like receptor; PPV, positive predictive value; NPV, negative predictive value; AUC, area under curve.

the metastatic patients compared with the non-metastatic patients $(\mathrm{P}=0.001$; Table II). No significant differences in estrogen receptor (ER) expression, menopausal status and pathology were detected between patients with metastatic and non-metastatic breast cancer (Table II).

Serum sTLR2. A high significant increase in the levels of serum sTLR2 were detected in patients with both metastatic $(5,997.4 \pm 8,585.23)$ and non-metastatic $(2,258.2 \pm 1,832.44)$ breast cancer, compared with the control group $(1,106.8 \pm 99.93)$ $(\mathrm{P}=0.0001$; Table III) (Fig. 1). Furthermore, a highly significant increase in serum sTLR2 was detected in metastatic breast cancer patients $(5,997.4 \pm 8,585.23)$ compared with non-metastatic patients (2,258.2 $\pm 1,832.44 ; \mathrm{P}=0.0001$; Table III) (Fig. 1).

Serum sTLR4. Compared with the healthy control group $(1,106.8 \pm 108.32)$, a highly significant increase in serum sTLR4 level was detected in both metastatic $(7,800.1 \pm 13,041.28)$ and non-metastatic $(1,945.2 \pm 1,709.53)$ patients $(\mathrm{P}=0.0001$; Table IV) (Fig. 1). The increase in serum sTLR4 between metastatic and non-metastatic patients was also observed ( $\mathrm{P}=0.0001)$ (Table IV) (Fig. 1).

Correlation between serum sTLR2 and 4 expression and clinicopathological parameters of patients with breast cancer. A significant negative correlation between serum sTLR4 and distant metastasis ( $\mathrm{r}=-0.303 ; \mathrm{P}=0.002)$ (Table V and Fig. 2B) was observed in patients with breast cancer. A negative correlation was also detected between serum sTLR2 and distant metastasis ( $\mathrm{r}=-0.291 ; \mathrm{P}=0.003)$ (Table V and Fig. 2C). sTLR4 expression was positively correlated with that of $\mathrm{PR}(\mathrm{r}=0.196$; $\mathrm{P}=0.05$ ) (Table V and Fig. 2A), but not with HER-2 and ER expression, lymphovascular invasion, number of lymph nodes, tumor size and tumor grade in patients with breast cancer (Table V).

On the other hand, breast cancer patients showed no significant correlation between serum sTLR2 and other clinicopathological parameters, such as HER2, progesterone and estrogen receptor expression, lymphovascular invasion, number of lymph nodes, tumor size and tumor grade (Table V).

Sensitivity and specificity of serum STLR2. ROC analysis revealed a significant increase in sensitivity, specificity and accuracy $(\mathrm{P}=0.008)$. For sTLR2, the AUC was 0.634, sensitivity was $65 \%$, specificity was $70 \%$ and accuracy was $69 \%$ (Table VI and Fig. 3A).

Table VI. Sensitivity, specificity and accuracy of sTlr2 detection.

Sensitivity and specificity of serum sTLR4. ROC curve analysis revealed no significant sensitivity, specificity or accuracy for the detection of sTLR4 as a marker for breast cancer (Table VI and Fig. 3B).

Sensitivity and specificity of serum STLR2 and serum TLR4 detection in patients with breast cancer. ROC curve analysis revealed non-significant increases in sensitivity, specificity and accuracy for combination detection of sTLR 2 and sTLR4 $(\mathrm{P}=0.217)$. The area under the ROC curve was 0.611 with a sensitivity of $63 \%$, specificity of $64 \%$ and an accuracy of $62 \%$ (Table VI and Fig. 3C).

\section{Discussion}

TLRs are widely expressed on tumor cells and are involved in the initiation and progression of breast cancer (15). TLR2 stimulation on the surface of breast cancer cells has been demonstrated to increase invasive potential by promoting NF- $\kappa B$ signaling (8). Breast cancer cells possess high expression levels of TLR4, indicating that this receptor is critical to the development of breast cancer (16).

The role of TLR2 and 4 signaling in breast cancer progression has been documented in a number of different studies, and both receptors have been implicated in the activation of various transcription factors, including NF- $\mathrm{kB}$ (17). It is therefore critical that the TLR system be tightly regulated in both the physiological and pathological state, as aberrant inflammatory reactions result in detrimental effects to the host (9).

To the best of our knowledge, the present study is the first to investigate the roles of sTLRs in breast cancer progression. On this basis, the aim of the present study was to assess the serum levels of sTLR2 and 4 as endogenous negative regulators of TLR2 and TLR4 signaling in patients with breast cancer, and to investigate their correlation with different clinicopathological parameters. The present study revealed an increase in serum sTLR2 and 4 levels, indicating their roles as endogenous 


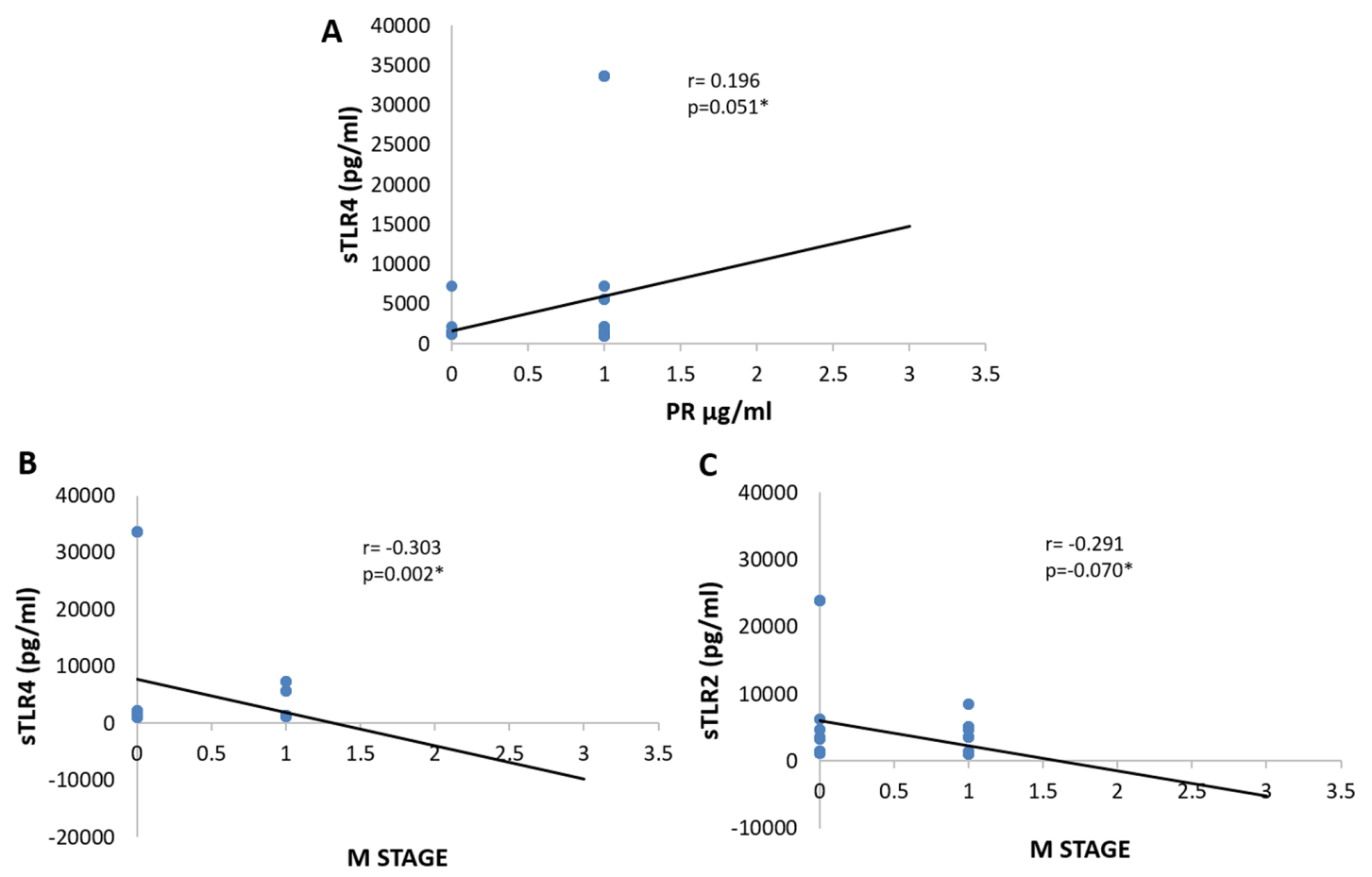

Figure 2. Correlation between serum sTLR2 and sTLR4 levels and the clinical characteristics of patients with breast cancer. (A) Significant positive correlation between sTLR4 and progesterone receptor expression. (B) Significant negative correlation between sTLR4 and distant metastasis. (C) Significant negative correlation between sTLR2 and distant metastasis. "P $\leq 0.05$. sTLR, soluble Toll-like receptor; PR, progesterone receptor; M, distant metastasis.
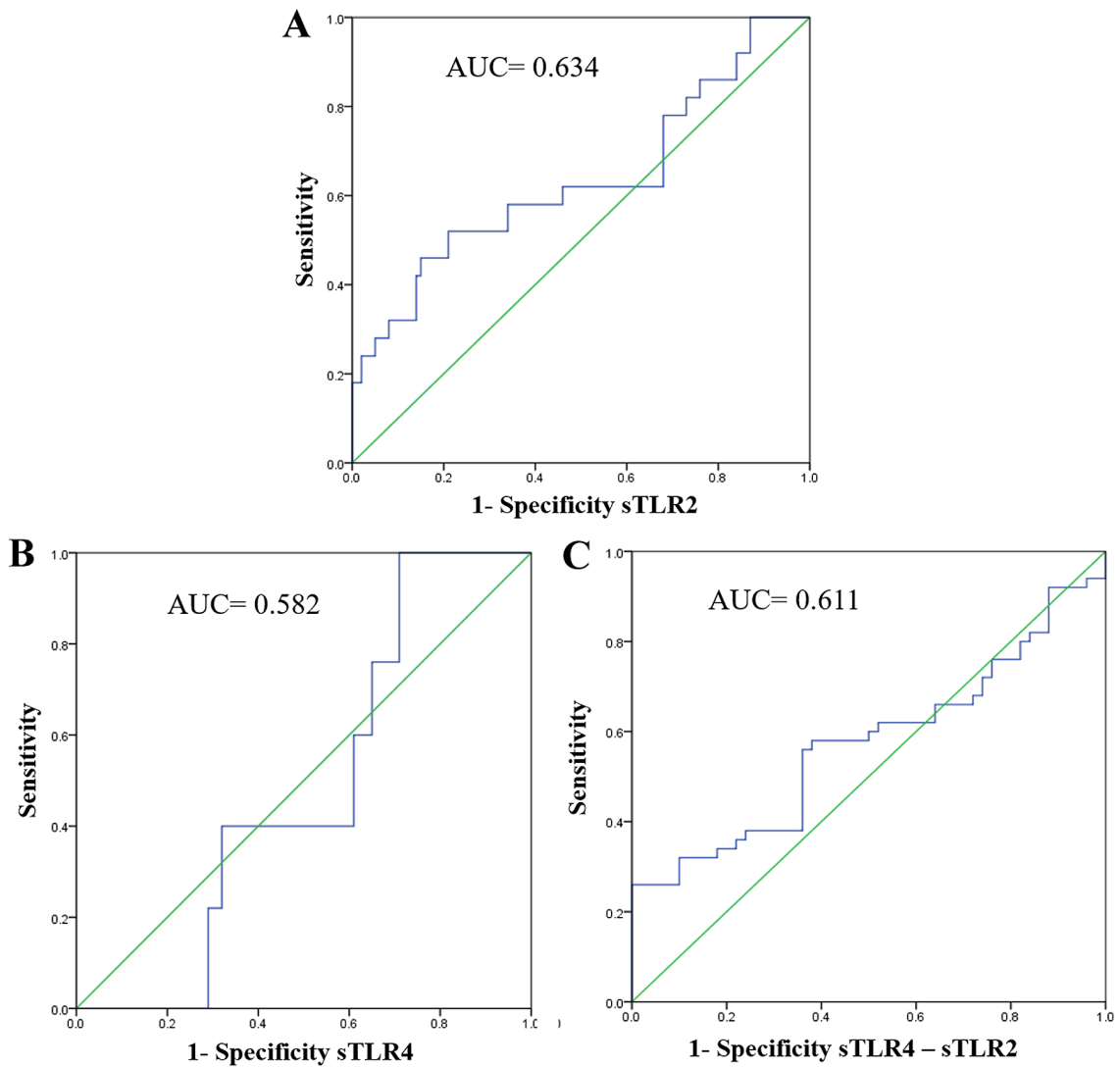

1- Specificity sTLR4 - sTLR2

Figure 3. Receiver operating characteristic curves for the combined metastatic prediction capacity of sTLR2 and sTLR4. (A) For sTLR2, the AUC was 0.634. (B) For sTLR4, the AUC was 0.582. (C) For sTLR2 and sTLR4 combined, the AUC was 0.611. sTLR, soluble Toll-like receptor; AUC, area under curve.

negative regulators of TLR2 and TLR4 signaling in breast cancer. This finding is consistent with a study conducted by
Houssen et al (9) in 2016. In 2018, Hossain et al (18) also observed increased serum sTLR2 concentrations in a number 
of inflammatory diseases and disease models, including severe bacterial infection (19), multiple sclerosis (18), experimental human endotoxemia (13) and the autoimmune disease systemic lupus erythematous (SLE), where it serves as a biomarker for disease activity (9). This increase was attributed to the negative regulatory roles of sTLRs, which are achievable via different molecular mechanisms (18). Firstly, sTLRs act as decoy receptors by binding to ligands recognized by TLR2, without activating intracellular signaling cascades, thus reducing the efficiency of TLR2 signaling (18). The second mechanism is via the disruption of the close proximity between TLR 2 and its coreceptor CD14, which is crucial for efficient signaling. Such disruption most likely results from the capacity of sTLR2 to interact with CD14 (20). Alternatively, sTLR2 may homodimerize with cell surface TLR2 to inhibit signaling via the membrane bound receptor (20).

Another novel observation of the present study was that serum sTLR4 levels are significantly elevated in patients with non-metastatic and metastatic breast cancer. This is in agreement with a previous study by Ten Oever et al (13), who demonstrated that sTLR4 levels were increased in those with inflammatory diseases, compared the controls subjects. Furthermore, Wei et al (21) investigated the clinical significance of serum sTLR4 in non-small cell lung cancer (NSCLC), and revealed a significant increase in sTLR4 in patients, compared with healthy controls.

As for the association between sTLR4 and clinicopathological parameters, a significant positive correlation was detected between sTLR4 and PR expression in patients with breast cancer. This was also in agreement with the study by Wei et al (21), who found a positive correlation between serum sTLR4 levels and tumor stage in patients with NSCLC.

Moreover, a negative correlation was also detected between STLR2 expression and distant metastasis. This was in agreement with the 2016 study by Houssen et al (9), where a significant negative correlation was observed between sTLR2 and the clinicopathological parameters of patients with SLE. Serum sTLR2 was not significantly correlated with clinicopathological parameters such as HER2 and PR expression, lymphovascular invasion, the number of effected lymph nodes, tumor size, grade and presentation of breast cancer, which was also in agreement with Houssen et al (9) in patients with SLE. This negative correlation may be ascribed to the role of TLR2 and 4 signaling in the activation of $N F-\kappa B$, that hence leads to increased expression of cytokines and chemokines associated with leukocyte recruitment, and subsequent inflammatory responses (8).

In the present study, the results of the ROC curve analysis for STLR4 were similar between patients with metastatic and non-metastatic breast cancer. This is supported by Ten Oever et al (13), who indicated that the level of sTLR4 could not significantly differentiate infectious from non-infectious inflammation when compared with c- reactive protein. The elevated levels of sTLR 4 and 2 as endogenous negative regulators may be of prognostic and therapeutic value, counteracting tumor immune evasion mediated by tumor cell TLRs signaling, which results in the production of the proinflammatory interleukins 6 and 12. These factors result in tumor cell resistance to natural killer cell attack and evasion from immune surveillance (22). These observa- tions are in agreement with those of Huang et al (23), who found that TLR4 expression may contribute to tumor cell immune evasion, since blocking the TLR4 pathway using small inhibitory RNA or TLR4 inhibitory peptides delays tumor growth and prolongs the survival of tumor-bearing mice.

The primary limitation of the current study is the small sample population. The expression levels of the studied markers were only detected by ELISA, therefore we can only hypothesize the role of sTLR2 and 4 as diagnostic and prognostic markers of breast cancer.

In conclusion, the results of the present study indicate that as endogenous negative regulators of TLR2 and TLR4 signaling, sTLR 2 and 4 may be susceptible diagnostic and prognostic markers for breast cancer. Further future studies are warranted to validate the prognostic roles of these soluble receptors, and as a promising target for personalized immunotherapy in patients with breast cancer.

\section{Acknowledgements}

The authors acknowledge the efforts of Dr Doaa Ali Abdelmonsif (Assistant Professor of Biochemistry, Faculty of Medicine, Alexandria University) for her valuable support.

\section{Funding}

No funding was received.

\section{Availability of data and materials}

All data generated or analyzed during this study are included in this published article.

\section{Authors' contributions}

MH designed the study and constructed the research plan, collected and reviewed the literature, revised all draft versions of the manuscript (including approving the final version) and supervised all experimental research. GEK performed laboratory analyses, reviewed the literature, and wrote the first and last versions of the paper. AG recruited the patients and collected the clinical data. TO revised the final version of the manuscript and contributed to the biochemical analysis. All authors read and approved the final manuscript.

\section{Ethics approval and consent to participate}

The present study was approved by the Ethics Committee of the Faculty of Pharmacy, Damanhour University (Damanhour, Egypt; reference no. 3/8 PB4). All patients provided written informed consent prior to study commencement.

\section{Patient consent for publication}

Not applicable.

\section{Competing interests}

The authors declare that they have no competing interests. 


\section{References}

1. Nur Husna SM, Tan HT, Mohamud R, Dyhl-Polk A and Wong KK: Inhibitors targeting CDK4/6, PARP and PI3K in breast cancer. A review. Ther Adv Med Oncol 10: 1758835918808509, 2018.

2. Dubey AK, Gupta U and Jain S: Breast cancer statistics and prediction methodology: A systematic review and analysis. Asian Pacific J Cancer Prev 16: 4237-4245, 2015.

3. Ayala-Cuellar AP, Cho J and Choi KC: Toll-like receptors: A pathway alluding to cancer control. J Cell Physiol 234: 21707-21715, 2019.

4. McGettrick AF and O'Neill LA: Localisation and trafficking of Toll-like receptors: An important mode of regulation. Curr Opin Immunol 22: 20-27, 2010

5. Kawai T and Akira S: The role of pattern-recognition receptors in innate immunity: Update on Toll-like receptors. Nat Immunol 11: 373-384, 2010.

6. Ahmed A, Wang JH and Redmond HP: Silencing of TLR4 increases tumor progression and lung metastasis in a murine model of breast cancer. Ann Surg Oncol 20 (Suppl 3): S389-S396, 2013.

7. Grimmig T, Moench R, Kreckel J, Haack S, Rueckert F, Rehder R, Tripathi S, Ribas C, Chandraker A, Germer CT, et al: Toll like receptor 2,4 , and 9 signaling promotes autoregulative tumor cell growth and VEGF/PDGF expression in human pancreatic cancer. Int J Mol Sci 17: 2060, 2016.

8. Al-Harras MF, Houssen ME, Shaker ME, Farag K, Farouk O, Monir R, El-Mahdy R and Abo-Hashem EM: Polymorphisms of glutathione S-transferase $\pi 1$ and toll-like receptors 2 and 9: Association with breast cancer susceptibility. Oncol Lett 11: 2182-2188, 2016.

9. Houssen ME, El-Mahdy RH and Shahin DA: Serum soluble toll-like receptor 2: A novel biomarker for systemic lupus erythematosus disease activity and lupus-related cardiovascular dysfunction. Int J Rheum Dis 19: 685-692, 2016.

10. Dulay AT, Buhimschi CS, Zhao G, Oliver EA, Mbele A, Jing S and Buhimschi IA: Soluble TLR2 is present in human amniotic fluid and modulates the intraamniotic inflammatory response to infection. J Immunol 182: 7244-7253, 2009.

11. Henrick BM, Yao XD, Taha AY, German JB and Rosenthal KL: Insights into soluble Toll-like receptor 2 as a downregulator of virally induced inflammation. Front Immunol 7: 291, 2016.

12. Langjahr P, Díaz-Jiménez D, De la Fuente M, Rubio E, Golenbock D, Bronfman FC, Quera R, González MJ and Hermoso MA: Metalloproteinase-dependent TLR2 ectodomain shedding is involved in soluble toll-like receptor 2 (sTLR2) production. PLoS One 9: e104624, 2014.
13. Ten Oever J, Kox M, van de Veerdonk FL, Mothapo KM, Slavcovici A, Jansen TL, Tweehuysen L, Giamarellos-Bourboulis EJ, Schneeberger PM, Wever PC, et al: The discriminative capacity of soluble Toll-like receptor (sTLR)2 and sTLR4 in inflammatory diseases. BMC Immunol 15: 55, 2014.

14. Domenis R, Cifù A, Marinò D, Fabris M, Niazi KR, Soon-Shiong P and Curcio F: Toll-like receptor-4 activation boosts the immunosuppressive properties of tumor cells-derived exosomes. Sci Rep 9: 8457, 2019.

15. Bhattacharya D and Yusuf N: Expression of toll-like receptors on breast tumors: Taking a toll on tumor microenvironment. Int J Breast Cancer 2012: 716564, 2012.

16. Yang CX, Li CY and Feng W: Toll-like receptor 4 genetic variants and prognosis of breast cancer. Tissue Antigens 81: 221-226, 2013

17. Yusuf N: Toll-like receptors and breast cancer. Front Immunol 5: 84, 2014.

18. Hossain MJ, Morandi E, Tanasescu R, Frakich N, Caldano M, Onion D, Faraj TA, Erridge C and Gran B: The soluble form of toll-like receptor 2 is elevated in serum of multiple sclerosis patients: A novel potential disease biomarker. Front Immunol 9: 457, 2018

19. Holst B, Szakmany T, Raby AC, Hamlyn V, Durno K, Hall JE and Labéta MO: Soluble Toll-like receptor 2 is a biomarker for sepsis in critically ill patients with multi-organ failure within $12 \mathrm{~h}$ of ICU admission. Intensive Care Med Exp 5: 2, 2017.

20. Liew FY, Xu D, Brint EK and O'Neill LA: Negative regulation of toll-like receptor-mediated immune responses. Nat Rev Immunol 5: 446-458, 2005.

21. Wei F, Yang F, Li J, Zheng Y, Yu W, Yang L and Ren X: Soluble Toll-like receptor 4 is a potential serum biomarker in non-small cell lung cancer. Oncotarget 7: 40106-40114, 2016.

22. Huang B, Zhao J, Unkeless JC, Feng ZH and Xiong H: TLR signaling by tumor and immune cells: A double-edged sword. Oncogene 27: 218-224, 2008.

23. Huang B, Zhao J, Li H, He KL, Chen Y, Chen SH, Mayer L, Unkeless JC and Xiong H: Toll-like receptors on tumor cells facilitate evasion of immune surveillance. Cancer Res 65: 5009-5014, 2005.

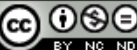

This work is licensed under a Creative Commons Attribution-NonCommercial-NoDerivatives 4.0 International (CC BY-NC-ND 4.0) License. 